\title{
Using the Financial Crisis to Reimagine the Private Sector
}

\author{
Sara J. Wolcott
}

\begin{abstract}
This article uses a workshop, organised by the think tank, Tomorrow's Company, to explore attempts to reimagine the role of business in development. In trying to envisage new ways of working between businesses and INGOs, workshop participants grappled with the tension between abstract thinking and the need to be practical and tangible. The challenges of imagining new ways of working together are highlighted in this article. Ultimately, it is the failure to visualise how change happens in a macro-setting that is seen as the key stumbling block to progress.
\end{abstract}

\section{Think tanks, INGOs, the private sector and a dynamic hegemony}

Even a cursory review of popular debate in 2008-10 reveals that the Financial Crisis of 2008 created space for a mainstream debate on the purpose of capitalism. How are international nongovernmental organisations (INGOs),

international businesses and think-tanks using the financial crisis as an opportunity to 'reimagine' the role of the private sector in development? This article highlights one of the many spaces where this debate was played out: a workshop in London hosted by a private-sector think tank, Tomorrow's Company (TC), ${ }^{1}$ in May 2010, with the aim of analysing the politics of change in this space at one point in time. TC brought together over 40 leaders from the private sector, INGOs and public bodies, such as the Department for International Development (DFID), to discuss building stronger relationships between INGOs and businesses, to reduce poverty. ${ }^{2}$

After giving some background to the debate around the relationship between the private sector, the 'third sector' and think-tanks, this article uses the workshop to explore three interrelated questions: (1) Are ideas about reimagining capitalism having any influence on relationships between firms, INGOs and the purpose of 'development'? (2) Recognising that think-tanks have historically exercised 'soft power' to influence thinking and policy culture (Parmar 2004; Wallace 2004), how is TC using the crisis to influence the spread of new ideas within the private sector and INGOs? (3) What are some of the barriers to reimagining, in this space, with these actors?

\subsection{Methods}

Informal interviews were conducted with the two key members of the TC staff who designed the workshop and four of the workshop participants two individuals from INGOs and two from the private sector (representing two major international corporations), who were open to having informal interviews. In addition, the article draws on workshop participant-observation, deskbased research and two interviews with academics in the field of corporate responsibility (CR), based on their published works in the area. Most corporate participants came from their firm's CR departments. Most of the participants came from large, international organisations, primarily based in the UK.

The analysis uses concepts of epistemic communities, building on Stone and Denham's (2004) research on the think tank's role in shaping and influencing ideas and institutions (Denham and Garnett 2004). It also follows Levy and Newell's (2002) use of the theories of political economy offered by Gramsci (1971). Gramsci views organisations such as firms, NGOs and think-tanks as inherently political (and social) actors. To what extent do they form alliances that secure 'hegemonic stability'

IDS Bulletin Volume 42 Number 5 September 2011 (C) 2011 The Author. IDS Bulletin (C) 2011 Institute of Development Studies Published by Blackwell Publishing Ltd, 9600 Garsington Road, Oxford OX4 2DQ, UK and 350 Main Street, Malden, MA 02148, USA 
(Levy and Newell 2004) - and how does that influence the ideas, policies and practices shaping international development? (Stone 2004).

\section{Background: Of course business has an impact on development!}

In the midst of the crisis, comments such as this from Zadek (2008) were common: 'no one will ever question the negative impact of irresponsible business practices, the source of the world's first global recession'. But just as both Mehta and Hossain (this IDS Bulletin) remind us that the 'crisis' discourse is not new for many communities on the ground, so we must remember that for many, the 'negative impact of irresponsible business practices' was not new: international 'development' has long been associated with environmental degradation often directly or indirectly caused by powerful interests. INGOs have long been engaged with variants of corporate responsibility (Arts 1998; Newell 2000), from encouraging civil regulation, to shareholder and legal activism, to taking on watchdog roles (Newell 2000, 2008; Welford 2002).

Businesses have, in turn, become increasingly sensitive to the damage INGOs can do and the support that INGOs can offer (Bendell 2004; Utting 2002). Simultaneously, the need to reconfigure the relationship between business and civil society in developing countries to achieve the goals of poverty reduction is part of the continuing public-private partnerships debate (Ford Foundation 2005; Fitzgerald and Cormack 2006; UNDP 2008; WBCSD 2005), which often discounts the role that INGOs can play (Hearfield 2010). But how much difference did the relative 'failure' of the dominant system make (capitalism fuelled by a version of economics that 'mistakes beauty for truth' as Paul Krugman (2009) puts it), to enable something 'new' to be created? How much can the dominant system change?

\section{The financial crisis opens space for discussing the role of businesses in development}

My informants suggested three primary ways in which the financial crisis directly affected the links between the private sector in the West and international development: (1) the consequences of the global recession in terms of reducing flows to international aid; (2) global power shifts - for many the result of the financial crisis was simply, 'Asia Up, US Down' (Malloch-Brown 2011) and
(3) questioning the best role of the private sector in furthering societal progress.

Between 2008 and 2010, capitalism 'became political again' (Bendell 2010), with frequent calls to 'rethink capitalism' (Inamori 2009). Much of this discourse re-affirmed capitalism with 'tweaks' (APABS 2009; Kinsley 2008); what Gramsci might consider as the dominant hegemony absorbing social pressures. These included: 'creative capitalism' to 'unleash' socialserving innovation (Kinsley 2008); 'conscious capitalism' to emphasise equalising social purpose and profit in the free market (Mackey 2007); 'post-Enlightenment capitalism', which functions for the 'greater good' (Vidal 2009) and 'reflexivity in markets' (Soros 2008).

More 'transformational' ideas were able to be aired and discussed, such as those in the UK Sustainable Commission's report, Prosperity without Growth? (Jackson 2009). Other ideas included 'capital democracy', i.e. advocating the social benefits of shifting property rights law (Bendell 2010); 'Capitalism 3.0', where 'businesses that 'serve the common good' and engage in 'deep reflection' (Scharmer 2010); and a 'great transition' from an unsustainable socioeconomy to a sustainable one (Simms et al. 2009). Within the realm of CR we are entering a new phase of CR, in which $\mathrm{CR}$ becomes a 'key condition for a continued global market economy' (Moller 2009). All of these ideas and calls to action reflect the desire for business models that better serve the public good.

TC workshop documents argued that the current constitution of the market leads to unsustainable outcomes for companies as well as society and that successful companies will be the ones to 'play a greater role in contributing to solving the problems that society faces' (Tomorrow's Company 2010: 3). But participants in the TC workshop did not overtly challenge capitalism. Partly, this is because challenging capitalism was not the workshop's aim. But a non-participant, Jem Bendell, editor of the Corporate Citizenship Journal, noted that this reflected a wider trend in the private sector:

\footnotetext{
I have not heard managers or executives discussing changing capitalism... People in companies don't know how to relate to and act on the awareness they have about systemic problems driving the risks and the
} 
- Vision vs implementation; practitioners often turn away from 'big ideas' as being 'impractical' - difficulty in knowing when, where and how vision and practical tools should be integrated;

- Lack of clarity of who has the responsibility, the agency and the influence to change the sector. Is it 'leadership'? Whose? How to influence it?;

- Disparate ideas, from changing capitalism to moving 'development' from philanthropy to core business practices remain unlinked and not cohesive;

- Structural barriers to change (e.g. market conditions which do not favour focusing on 'development' at the expense of profit, regardless of framing);

- Abstract, opinion-centred talk and ideas that do not give room for in-depth, thoughtful consideration.

difficulties they are having. As a result, the actual tangible projects that come from that realisation are few and far between... The global debate, such as the discussion on the UN global compact, is still trying to appeal to the lowest common denominator.

(Bendell 2010, pers comm)

Space clearly opened for new discourse. In many respects, participants from the private sector and the INGOs found it difficult to imagine themselves within it. But the TC workshop illustrates how it, as a think tank, was able to help some participants use this new space.

\section{A think tank uses the newly open space}

Tomorrow's Company used the space of the financial crisis to extend their long-held concern of supporting businesses to act 'responsibly' on behalf of all their stakeholders into what is, for them, the new arena of international development. That they, who have traditionally been focused within the UK and 'Western' businesses, are looking at international development, affirms the larger trends of the business sector (including their sources of intellectual capital) paying greater attention to the 'space' of international development.

Their workshop posed the question: How can the private sector be encouraged and supported in practical and concrete terms to transform the magnitude of its contribution to reducing global poverty? Their year-long research prior to the workshop suggested that 'old certainties and old scapegoats need to be fundamentally reassessed' and that 'both the private and the NGO sectors are standing at the point of profound change reflected in an examination of purpose, of strategy and of relationship' (Tomorrow's Company 2010: 2, 7).

TC, like most think-tanks, walk a tightrope between being 'innovative' and pushing the dominant discourse but simultaneously not being so distant that they have no influence. This workshop offered the chance for small group discussions on concrete actions the INGOs and companies could take to enable 'inclusive businesses' (HKS 2010) that 'build bridges between business and the poor for mutual benefit' (UNDP 2008).

Both sectors were enthusiastic about having the chance to network and meet in the 'safe space' TC provided - a key value added of think-tanks (Stone 1999). And TC certainly did not expect one workshop to 'solve' anything - it is the follow-up conversations where the real work of reimagining is expected to take place.

But even in what they described as a 'safe space' for open dialogue, reimagining had its challenges. The main issue seemed to be the tension between wanting to think conceptually and the perceived pressure to come up with concrete actions. For example, TC initially proposed outlining some 'principle conditions' to support companies to be effective forces for good in international development (e.g. creating jobs that offer decent and fair working conditions). These 'principle conditions' were met with resistance - most participants felt the exercise to 
be too abstract and therefore unhelpful. Participants wanted something more 'real'.

Perhaps this is not simply a reflection of a practitioner bias towards seeking practical action, but rather a dynamic of one of the real challenges of reimagining: to go beyond abstract discussion with multiple stakeholders who hold competing, as well as common, interests (Yankelovich 1991). Throughout the workshop, there was consistent tension between participants wanting to engage in visioning and often, the same participants cutting themselves off from visioning by the perceived imperative of rapidly achieving 'real' and 'practical action'.

\section{The workshop: comforting pragmatism?}

Workshop participants agreed that they wanted 'transformative change', but could not articulate a shared definition. There was much talk by the business community of the need to 'put aside historical differences' with INGOs. This was met with caution by many in the INGO community, even those with less history of confrontation with the private sector. This separateness was illustrated by a participant from a multinational company who pointed out that just as companies had CR teams separate from main operations, so NGOs have business teams separate from their main operations. Unsurprisingly, the 'lack of trust' was agreed upon as a barrier for working together - a familiar dynamic between unusual bedfellows (Knorringa and Helmsing 2008).

Despite this, participants created ideas about the potential benefits of closer work. These included: improving corporate public image; attracting 'high-quality' employees who seek to 'make a difference'; a company's desire to have access to communities in emerging markets; and cooperating with NGOs where there are shared interests, such as lobbying for changes in the law and regulations. Specific suggestions included businesses' desire for indicators to measure social, environmental and 'developmental' impact; baseline data and follow-up data to evidence what works, projects to learn how to work with INGOs (and local partners) and building trusting relationships.

But many proposals were for projects rather than the potentially more transformative initiatives aimed at tackling systemic issues. Of course, this is a fundamental challenge in any social change process, whether it involves the private sector or not.

\section{Going forward - with few signs of transformation}

It might be seen as ironic that just as capitalism is questioned, many of these larger INGOs are moving into closer relationships with businesses. Perhaps more accurately, both sectors took advantage of an opening presented by the financial crisis to strengthen the relationships with each other. For socially responsible businesses, here was an opportunity to get ahead by differentiating themselves from the 'bad guys'. For INGOs, here was an opportunity to influence powerful actors who were increasingly attuned to poverty reduction and environmental management.

But did the 'crisis' in the dominant capitalistic model really change perceptions or actions? The private sector participants in the TG workshop found it uncomfortable to challenge core assumptions about markets, often defaulting to marginal changes. Similarly, INGOs found it hard to face their own conflicted feelings about working hand in hand with private sector actors. Perhaps it was the enormity and abstractness of the ideas and assumptions that participants felt needed to be challenged, which made their desire to hold onto smaller but more practical actions so comforting. The tendencies of both sectors to think via programmes and projects and to work the system (but feel unable to challenge the fundamentals) may also contribute to this.

Ultimately, the workshop participants seemed to be skirting around the question of 'how change happens' in a macro-system. Can the microchanges trigger macro-changes? There was hope that they could, but as Utting (2002) points out, the track record is not good. Without a changing structure to work in, even progressive leaders in the private sector feel constrained. It seems that both sectors are so entangled in the dominant model that true transformation of, or from, either sector remains difficult - despite the space opened by the financial crisis and the ongoing facilitation of think-tanks like TC.

Effective reimagining needs to take account of the larger ideas in the 'macro' space and provide opportunities for actors from multiple perspectives to create shared meaning and 
visions and talk through the abstractions into practical tools and actions. This is a long-term process; workshops are but one resting stop on a long road of actors seeking to change and influence the ideas that shape and even define these complex relationships. Think tanks can play a critical role in providing the space for reflection, strengthening relationships and building intellectual capital. The more all these actors can prepare intellectual and relationship capital for the intellectual and policy openings that crises present, the more capacity they have to actively effect change.

Part of the challenge is that development relies on collective action between state and society in

\section{Notes}

1 www.tomorrowscompany.com (accessed 15 March 2010).

\section{References}

APABS (Asian-Pacific American Business Summit) (2009) 'Current Global Financial Trend', Washington DC, 14-16 February

Arts, B. (1998) The Political Influence of Global NGOs: Case Studies on the Climate Change and Biodiversity Conventions, Utrecht: International Books

Bendell, J. (2004) Barricades and Boardrooms: A Contemporary History of the Corporate Accountability Movement, Programme Paper (TBS) 13, Geneva: United Nations Research Institute for Social Development (UNRISD)

Bendell, J., with Doyle, I.; Cohen, J.; Irwin, E. and Black, N. (2010) Capitalism in Question: The Lifeworth Annual Review of Corporate Responsibility in 2009, London: Lifeworth Consulting, www.lifeworth.com/capitalisminquestion.pdf (accessed 7 June 2011)

Denham, A. and Garnett, M. (2004) 'A "Hollowed Out" Tradition? British Think Tanks in the Twenty-first Century', in D. Stone and A. Denham (eds) Think Tank Traditions: Policy Research and the Politics of Ideas, Manchester: Manchester University Press

Fitzgerald, N. and Cormack, M. (2006) The Role of Business in Society: An Agenda for Action, New York: JFK School of Government

Ford Foundation (2005) Part of the Solution: Leveraging Business and Markets for Low-Income People, New York: Ford Foundation, www.bwbsolutions.com/pdf/FordFoundationPartoftheSolution-ExecutiveSummary.pdf (accessed 10 May 2010) all its forms. As one workshop participant said, with so many different actors, 'who has responsibility for development?' Critically missing was the perspective of Southern voices. Similarly, in the shifting global power relationships, how much do workshops in London actually impact either intellectual or practical results around the world? The global economic crisis may have ushered in some new development relationships and intensified others, but it is up to all of us to make them work for development - so the de facto position that 'what is everyone's business becomes nobody's business' does not merely muddle onward.

2 Examples of participating organisations include the BodyShop and WWF-UK.

Gramsci, A. (1971) Selections from Prison Notebooks, New York: International Publishers

Hearfield, C. (2010) Tomorrow's Force for Good, report for Tomorrow's Company, London: Tomorrow's Company

HKS (Harvard Kennedy School) (2010) Scaling Up Inclusive Business: Advancing the Knowledge and Action Agenda, Boston: International Finance Corporation (IFG)

Inamori, Kazuo (2009) 'Kyocera Founder Inamori Criticizes US CEO Excesses', USA Today, www.usatoday.com/money/companies/ management/advice/2009-04-19-adviceinamori_N.htm (accessed 2 August 2010)

Jackson, T. (2009) Prosperity without Growth, London: Sustainable Development Commission, www.sd-commission.org.uk/.../ prosperity_without_growth_report.pdf (accessed 15 October 2009)

Kinsley, M. (2008) Creative Capitalism, New York: Simon and Schuster

Knorringa, P. and Helmsing, A.H.J. (2008) 'Beyond an Enemy Perception: Unpacking and Engaging the Private Sector', Development and Change 39.6: 1053-78

Krugman, P. (2009) 'How did Economists get it so Wrong?', New York Times, 2 September 2009, www.nytimes.com/2009/09/06/magazine/ 06Economic-t.html (accessed 31 May 2011)

Levy, D. and Newell, P. (2004) 'A Neo-Gramscian Approach to Business in Environmental Politics: An Inter-disciplinary, Multi-level Framework', in D. Levy and P. Newell (eds), 
The Business of Global Environmental Governance, Boston: MIT Press: 47-69

Mackey, J. (2007) Conscious Capitalism: Creating a New Paradigm for Business, Whole Foods Inc., www.wholeplanetfoundation.org/files/uploaded/ John_Mackey-Conscious_Capitalism.pdf (accessed 2 September 2010)

Malloch-Brown, L. (2011) Davos 2011: The World's Grandest Focus Group?, BBC News, www.bbc.co.uk/news/business-12239764 (accessed 7 June 2011)

Moller, K. (2009) How the Global Financial Crisis is Strengthening Corporate Social Responsibility, www.oxfordleadership.com/CSR_Article (accessed 1 August 2010)

Newell, P. (2008) 'Civil Society, Corporate Accountability and Climate Change', Global Environmental Politics 8.3: 122-50

Newell, P. (2000) Climate for Change: Non-State Actors and the Global Politics of the Greenhouse, Cambridge: Cambridge University Press

Parmar, I. (2004) 'Institutes of International Affairs: Their Roles in Foreign Policy Making, Opinion Mobilization and Unofficial Diplomacy', in D. Stone and A. Denham (eds), Think Tank Traditions: Policy Research and the Politics of Ideas, Manchester: Manchester University Press

Scharmer, O. (2010) 'Seven Acupuncture Points for Shifting Capitalism to Create a Regenerative Ecosystem Economy', Oxford Leadership Journal 1.3: 1-21

Simms, A. et al. (2009) Other Worlds are Possible, The Sixth Report from the Working Group on New Economics, London: New Economic Foundation

Soros, G. (2008) Reflexivity in Financial Markets: The New Paradigm for Financial Markets: The Credit Crisis of 2008 and What it Means, 1st edn, New York: Public Affairs

Stone, D. (2004) 'Introduction: Think Tanks, Policy Advice and Governance', in D. Stone and A. Denham (eds) Think Tank Traditions: Policy Research and the Politics of Ideas, Manchester: Manchester University Press
Stone, D. (1999) 'Introduction: Think Tanks, Policy Advice and Governance', in D. Stone and A. Denham (eds), Think Tank Traditions: Policy Research and the Politics of Ideas, Manchester: Manchester University Press Stone D. and A. Denham (eds) (2004) Think Tank Traditions: Policy Research and the Politics of Ideas, Manchester: Manchester University Press

Tomorrow's Company (2010) Tomorrow's Force for Good: Transforming the Private Sector's Contribution to International Development, London:

Tomorrow's Company

UNDP (2008) Creating Value for All: Strategies for doing Business with the Poor, New York: United Nations Development Programme

Utting, P. (ed.) (2002) 'Introduction', in The Greening of Business in Developing Countries: Rhetoric, Reality and Prospects, London: Zed Books: 5-35

Vidal, D. (2009) 'Post-Enlightenment Capitalism', Journal of Corporate Citizenship 34: 23-5

Wallace, W. (2004) 'Afterward: Soft Power, Global Agendas', in D. Stone and A. Denham (eds), Think Tank Traditions: Policy Research and the Politics of Ideas, Manchester: Manchester University Press

Welford, R. (2002) 'Disturbing Development: Conflicts between Corporate Environmentalism, the International Economic Order and Sustainability', in P. Utting (ed.), The Greening of Business in Developing Countries: Rhetoric, Reality and Prospects, London: Zed Books: 135-58

WBCSD (2005) Business for Development: Business Solutions in Support of the Millennium Development Goals, Geneva: World Business Council for Sustainable Development

Yankelovich, D. (1991) Coming to Public Judgment: Making Democracy Work in a Complex World, Syracuse NY: Syracuse University Press

Zadek, S. (2008) All the King's Horses, Accountability, 31 December 2008, www.accountability21.net (accessed 7 June 2011) 